\title{
Anthelmintic Efficacy of Polyherbal Formulation in Goats Naturally Infected with Haemonchus contortus
}

\author{
Vinayak Khanolkar*, C.G. Panchbhai, G.R. Bhojne, V.M. Dhoot and A.J. Athaley \\ Department of Veterinary Clinical Medicine, Ethics and Jurisprudence, Nagpur Veterinary \\ College, Nagpur, India \\ *Corresponding author
}

\begin{tabular}{|l|}
\hline K e y w or d s \\
$\begin{array}{l}\text { Artimisia maritima, Butea } \\
\text { frondosa, Vernonia } \\
\text { anthelmintica, } \\
\text { Holarrhena } \\
\text { antidysentrica }\end{array}$ \\
\hline Article Info \\
\hline $\begin{array}{l}\text { Accepted: } \\
\text { 15 September } 2018 \\
\text { Available Online: } \\
10 \text { October } 2018\end{array}$ \\
\hline
\end{tabular}

\section{Introduction}

Small ruminant rearing is an asset of livelihood for the farmers among poor and developing countries. The diseases caused by helminth parasitism especially gastrointestinal parasitism in small ruminants are one of the major health problems and productivity constraints in the tropics and subtropics. Mini et al., (2013) reported that among the various
The study was conducted at Department of Veterinary Clinical Medicine, Ethics and Jurisprudence. The polyherbal tablet comprising Artimisia maritima, Butea frondosa, Vernonia anthelmintica and Holarrhena antidysentrica was prepared and its anthelmintic efficacy and effect on body weight was studied on goats naturally infected with Haemonchus contortus. Total 140 goats were selected which were naturally infected with Haemonchus contortus. Out of 140 goats, 100 goats were selected as Group I (Polyherbal Treatment), 20 goats were selected as Group II (Positive control) and 20 goats were selected as Group III (Negative control), respectively. For the positive control albendazole $(10 \mathrm{mg} / \mathrm{kg} \mathrm{BW})$ was given to the control group goats and in negative control goats maintained untreated. Group I animals were given polyherbal polymer complex anthelmintic and Group II animals were given albendazole. The faecal samples were examined on $0^{\text {th }}$ day before and $3^{\text {rd }}, 7^{\text {th }}, 15^{\text {th }}$ and $30^{\text {th }}$ day post treatment. Body weights of goats under treatment were recorded on day 0 i.e. before treatment and on $15^{\text {th }}$ and $30^{\text {th }}$ day post treatment. There was significant reduction in Egg per Gram (EPG) count seen in Group I and Group II, whereas, the EPG count increased significantly in Group III. Increase in body weight was observed significantly in Group I and Group II whereas, there was decrease in body weight observed in Group III. Further it was concluded that the polyherbal anthelmintic tablet was effective in elimination of Haemonchus contortus which could be the reason for increase in body weight during the trial. 
highly pathogenic nematode parasite capable of causing acute disease and high mortality. McKenna et al., (1995), Chartier et al., (2001) and Soulsby (2006) reported that haemonchosis is characterized by haemorrhagic anaemia due to the blood sucking activities of the worms in the abomasum. The morbidity is observed through anaemia and gastroenteritis resulting into loss of body weight, stunted growth, diarrhoea etc. that greatly hampers the normal growth and production of goats.

In developing countries, the expensiveness and unavailability of these drugs is a main hurdle to farmers in rural areas. Waller and Prichard (1985) discussed that the control of this parasite over the past five decades has been achieved mainly through intensive use of synthetic anthelmintic drugs. The repetitive and improper dosing of synthetic anti-parasitic products has led to the development of Anthelmintic Resistance (AR). Also, there is a problem of chemical residue and toxicity of synthetic anthelmintics. Mohammed et al., (2013) reported that conventional method of controlling parasites by just using chemical dewormer is ineffective. For several reasons, this parasite is developing resistance against most of the chemical dewormers available in the market.

A need to decrease the reliance on these chemotherapeutic drugs for parasite control was discussed by Chandrawathani et al., (2003) and Githiori (2004) the growing concerns about the adverse consequences on the ecosystem and biodiversity.

This menace has given impetus to the search for new drugs, with attention focusing on the search and application of plant products as alternative methods of parasite control. Alternate options like traditional medicinal plants and biological control are getting attention.
Ethno-veterinary Medicine (EVM) are becoming more relevant. Ferreira et al., (2013) reported that the uses of plants with anti-parasitic properties as well as the use of traditional herbal remedies. Satpute et al., (2014) reported that for many centuries, plants have been providing various remedies for several diseases. Herbal medicine has been the base of treatment in India since ages and has been demonstrated in Ayurveda, Unani and Sidha.

There are currently an increasing number of controlled experimental studies that aim to verify, validate and quantify the property of a particular plant. The development of herbal product depends upon the local botanical flora. A larger number of plants are naturally available which possess ability of treating many parasitic diseases of livestock. David (1990) reported that several medicinal plants have been investigated for their anthelmintic properties; however, scientific evidence on the anthelmintic efficacy of most plant products is limited, regardless of their wide ethno veterinary usage.

Based on the information obtained from ethno-medicinal survey and Indian traditional medicinal system, has made use of the different parts of plants in different types of diseases including anthelmintic activities. Kirthikar and Basu (1975) reported that Butea frondosa, popularly known as 'palas', is commonly distributed throughout India. Seeds of $B$. frondosa are reported to have anthelmintic property and largely used in treatment of round worms. Zafar et al., (2006) reported that Vernonia anthelmintica seeds possess anthelmintic activity against nematodes. Zafar et al., (2004) reported that some species of genus Artemisia like Artemisia maritima have been evaluated for their anthelmintics activity. Satpute et al., (2014) reported that the stembark of Holarrhena antidysentrica was also 
traditionally used to treat nematode infestation in goats.

The anthelmintic drugs of plant origin are safer and affordable to resource limited small scale livestock keepers, and thus there is need to scientifically validate their use through research and will lay a foundation and set a targeted platform for ethno-pharmacological studies and development of novel anthelmintic product. Sunandhadevi et al., (2017) proposed that a polyherbal anthelmintic formulation of Butea frondosa, Vernonia anthelmintica, Artemisia maritima and Holarrhena antidysentrica could have a synergistic effect among the phytochemicals of the plants used.

The present study is proposed for the evaluation of the anthelmintic efficacy of the polyherbal formulation comprising of Artemisia maritima, Butea frondosa, Holarrhena antidysentrica and Vernonia anthelmintica with $\mathrm{pH}$ sensitive polymer coated targeted tablet and its effect on body weight of Haemonchus contortus infected goats.

\section{Materials and Methods}

The formulation of dose of four herbal extracts viz. Artimisia maritima $(75 \mathrm{mg} / \mathrm{ml})$, Butea frondosa (200mg/ml), Vernonia anthelmintica $(75 \mathrm{mg} / \mathrm{ml})$ and Holarrhena antidysentrica $(75 \mathrm{mg} / \mathrm{ml})$ was done at Department of Veterinary Medicine, Ethics and Jurisprudence; Nagpur Veterinary College Nagpur (Panchbhai, 2018) and hence the same preparation was used in the present study. The tablet formulated was $\mathrm{pH}$ dependent and disintegrates in an acidic $\mathrm{pH}$ (2-4) of abomasum.

Total 140 goats were selected on the basis of faecal sample collected and examined before treatment. Out of 140 goats, 100 goats were selected as Group I (Polyherbal Treatment),
20 goats were selected as Group II (Positive control) and 20 goats were selected as Group III (Negative control), respectively. For the positive control albendazole (10 $\mathrm{mg} / \mathrm{kg} \mathrm{BW})$ was given to the control group goats and in negative control goats maintained untreated. Goats naturally infested with Haemonchus contortus were selected by examining the faecal sample by standard sedimentation and salt floatation techniques as described by Soulsby (1982). Further, positive samples were examined by Modified Stoll's dilution technique as described by Soulsby (1982) on 0 day before and $3^{\text {rd }}, 7^{\text {th }}, 15^{\text {th }}$ and $30^{\text {th }}$ day post treatment to determine the Egg per Gram of faeces (EPG). Body weights of goats under treatment were recorded on day 0 i.e. before treatment and on $15^{\text {th }}$ and $30^{\text {th }}$ day post treatment.

\section{Results and Discussion}

\section{Egg per gram count}

The average EPG value (Table 1) (Fig. 1) in Group I observed in goats infested with $H$. contortus on the onset of study was $1520.00 \pm$ 29.54 indicating heavy parasitism in the selected goats. After administration of polyherbal tablet, the average of EPG value on $3^{\text {rd }}$ day was $194.00 \pm 13.39$. Thereafter, on $7^{\text {th }}$, $15^{\text {th }}$ and $30^{\text {th }}$ day post treatment the EPG values recorded were nil. In Group II, the EPG values before administration of albendazole was $1580.00 \pm 30.43$. Post treatment EPG value in positive control group on $3^{\text {rd }}$ day $260.00 \pm 11.23$; whereas, on $7^{\text {th }}, 15^{\text {th }}$ and $30^{\text {th }}$ day post treatment the EPG values observed were nil. However, in Group III, the EPG values recorded on the onset of study was $1590.00 \pm 29.82$ and on $3^{\text {rd }}, 7^{\text {th }}, 15^{\text {th }}$ and $30^{\text {th }}$ day were $1710.00 \pm 26.05,1745.00 \pm 27.60$,

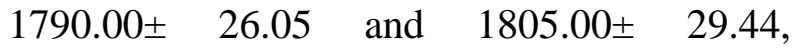
respectively. There was an increasing trend observed in the EPG values of Group III which indicate that infestation of Haemonchus 
contortus in goats was in an ascending pattern of parasitism.

Significant $(\mathrm{P}<0.01)$ difference in the EPG values on the onset of study and after administration of polyherbal tablet on $3^{\text {rd }}$ day was observed in Group I which indicated that the polyherbal tablet was effective from $3^{\text {rd }}$ day itself. Thereafter, EPG values observed on $7^{\text {th }}, 15^{\text {th }}$ and till $30^{\text {th }}$ day were nil indicating that there was efficient anthelmintic activity exhibited by the polyherbal tablet and no further infestation was observed for $30^{\text {th }}$ day. These observations are in corroboration with Zacharias et al., (2008) and Biswas et al., (2017).

Similarly, in Group II, there was significant $(\mathrm{P}<0.01)$ difference in the EPG values observed after administration of albendazole on $3^{\text {rd }}$ day. Further, EPG values observed after administration of albendazole on $7^{\text {th }}, 15^{\text {th }}$ and $30^{\text {th }}$ day were nil.

The reduction in the average EPG values from 0 day to $3^{\text {rd }}$ day was more significant $(\mathrm{P}<0.01)$ in Group I after administration of polyherbal tablet as compared to albendazole. Hence, it could be stated that polyherbal tablet was more effective than albendazole.

The average EPG count reduction in Group I after administration of polyherbal tablet on $3^{\text {rd }}$ day and till $30^{\text {th }}$ day was significant $(\mathrm{P}<0.01)$ as compared to Group III which showed an increasing trend in EPG count indicating persistence increasing infection of Haemonchus contortus in the goats in Group III.

In Group III, there was significant $(\mathrm{P}<0.01)$ difference observed in EPG values before the treatment and $3^{\text {rd }}, 7^{\text {th }}, 15^{\text {th }}$ and $30^{\text {th }}$ day post treatment, respectively. Similar observations were reported by Ameen et al., (2006) in which there were steady increase in the EPG count on $21^{\text {st }}$ day onwards, whereas Biswas et al., (2017) observed increase in EPG from 0 day to $28^{\text {th }}$ day, respectively.

In the present study, the faecal samples were examined on $3^{\text {rd }}, 7^{\text {th }}, 15^{\text {th }}$ and $30^{\text {th }}$ day post treatment for EPG count. However, no eggs were observed from $7^{\text {th }}$ day post treatment till $30^{\text {th }}$ day in Group I. The results corroborated with Bora and Sharma (2011) who opined that the anthelmintic activity of Artemisia maritima due to its active ingredient santonin; Mali and Mehta (2008) who observed that anthelmintic activity of Butea frondosa is due to palasonin; Shah et al., (2010) who referred that conessine is the active phyto-constituent which is responsible for anthelmintic activity of Holarrhena antidysentrica; Zafar et al., (2006) who described Vernolic acid is the active ingredient in Vernonia anthelmintica exhibiting anthelmintic activity. Hence in the present study the significant anthelmintic activity of polyherbal formulation in Group I might be due to the synergistic effect of Artemisia maritima, Butea frondosa, Holarrhena antidysentrica and Vernonia anthelmintica.

\section{Body weight}

In Table 3 (Fig. 2) the average body weight observed in Group I on the onset of study was $18.73 \pm 0.20 \mathrm{~kg}$. The average body weights after administration of polyherbal tablet on $15^{\text {th }}$ day and $30^{\text {th }}$ day were $19.00 \pm 0.20 \mathrm{~kg}$ and $19.41 \pm 0.20 \mathrm{~kg}$, respectively.

In Group II the average body weight before the commencement of study was $17.78 \pm 0.40$ $\mathrm{kg}$ and after administration of albendazole on $15^{\text {th }}$ and $30^{\text {th }}$ day were $17.93 \pm 0.39 \mathrm{~kg}$ and $18.09 \pm 0.40 \mathrm{~kg}$, respectively. Whereas, in Group III the average body weight observed on the onset of study was $19.94 \pm 0.31 \mathrm{~kg}$ and on $15^{\text {th }}$ and $30^{\text {th }}$ day were, $19.77 \pm 0.31 \mathrm{~kg}$ and $19.52 \pm 0.31 \mathrm{~kg}$, respectively. 
Table.1 Average ( \pm S. E.) of Egg per Gram (EPG) before and after treatment in goats

\begin{tabular}{|c|c|c|c|c|c|c|}
\hline \multirow[t]{2}{*}{ Group } & \multicolumn{5}{|c|}{ EPG } & \multirow{2}{*}{$\begin{array}{l}\text { Pooled } \\
\text { Average } \\
\text { (Group) }\end{array}$} \\
\hline & $0^{\text {th }}$ day & $3^{\text {rd day }}$ & $7^{\text {th }}$ day & $15^{\text {th }}$ day & $30^{\text {th }}$ day & \\
\hline $\begin{array}{c}\text { Group - I } \\
\text { (Polyherbal } \\
\text { treatment) }\end{array}$ & $\begin{array}{c}1,520.00 \pm 2 \\
9.54^{\mathrm{a}}\end{array}$ & $\begin{array}{c}194.00 \pm 13 \\
.39^{\mathrm{b}}\end{array}$ & $00 \pm 00.00^{c}$ & $00 \pm 00.00^{\mathrm{d}}$ & $00 \pm 00.00^{\mathrm{e}}$ & $\begin{array}{c}342.80 \pm 27.3 \\
4^{\mathrm{A}}\end{array}$ \\
\hline $\begin{array}{l}\text { Group- II } \\
\text { (Positive } \\
\text { control) } \\
\end{array}$ & $\begin{array}{c}1,580.00 \pm 3 \\
0.43^{\text {af }}\end{array}$ & $\begin{array}{c}260.00 \pm 11 \\
.23^{\mathrm{g}}\end{array}$ & $00 \pm 00.00^{\mathrm{h}}$ & $00 \pm 00.00^{i}$ & $00 \pm 00.00^{\mathrm{j}}$ & $\begin{array}{c}368.00 \\
\pm 62.07^{\mathrm{B}}\end{array}$ \\
\hline $\begin{array}{l}\text { Group -III } \\
\text { (Negative } \\
\text { control) }\end{array}$ & $\begin{array}{c}1,590.00 \pm 2 \\
9.82^{\mathrm{ak}}\end{array}$ & $\begin{array}{c}1,710.00 \pm \\
26.05^{1}\end{array}$ & $\begin{array}{c}1,745.00 \pm 2 \\
7.60^{\mathrm{m}}\end{array}$ & $\begin{array}{c}1,790.00 \pm \\
26.05^{\mathrm{n}}\end{array}$ & $\begin{array}{c}1,805.00 \pm \\
29.44^{\circ}\end{array}$ & $\begin{array}{c}1728.00 \pm 14 \\
43^{\mathrm{C}}\end{array}$ \\
\hline \multicolumn{2}{|c|}{ Critical Difference (C.D.): } & $\begin{array}{l}\text { For Group: } \\
\text { for Interval: }\end{array}$ & $\begin{array}{l}1.20344 \\
2.40688\end{array}$ & & & \\
\hline
\end{tabular}

Note - Small letters indicate comparison between the days (column wise) for $1 \%$ level of significance.

Capital letters indicate comparison between different treatments (row wise) for $1 \%$ level of significance.

Table.2 Analysis of variance using unequal factorial design with unequal number of observations for average Egg per Gram (EPG) before and after treatment in goats

\begin{tabular}{|l|l|l|l|l|l|l|}
\hline Source & DF & SS & MSS & F (Cal) & F - 0.05 & F - 0.01 \\
\hline SS G & 2 & 163523862.9 & 81761931.4 & 4563.98888 & 3.01 & $4.64^{* *}$ \\
\hline SS D & 4 & 175894714.3 & 43973678.6 & 2454.6311 & 2.38 & $3.35^{* *}$ \\
\hline GXD & 8 & 38479165.71 & 4809895.71 & 268.490607 & 1.95 & $2.54 * *$ \\
\hline Error & 686 & 12289400 & 17914.5773 & & & \\
\hline Total & 700 & & & & & \\
\hline
\end{tabular}

Table.3 Average ( \pm S. E.) of Body Weight $(B W)$ in Kg before and after treatment in goats

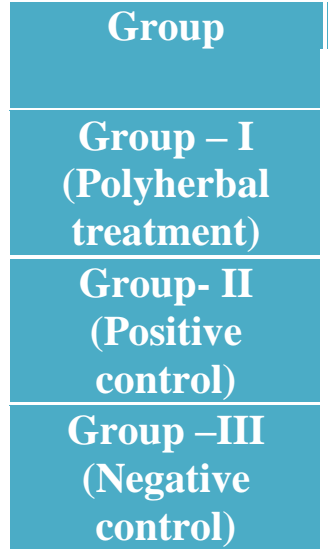

Critical Difference (C.D.):

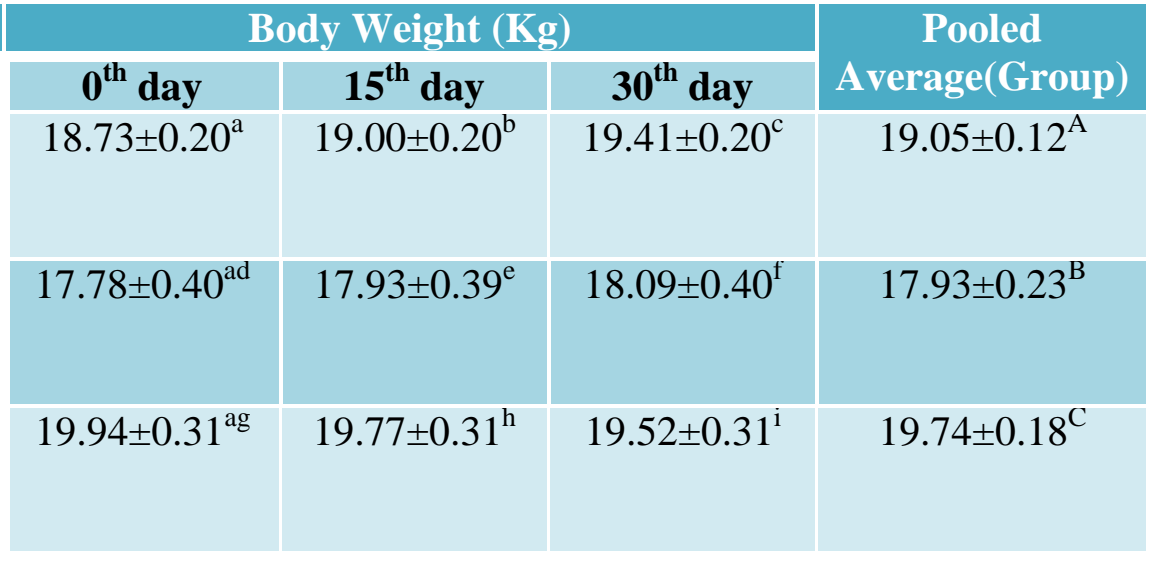

$\begin{array}{ll}\text { For Group: } & 0.03152 \\ \text { For Interval: } & 0.0315\end{array}$

Note - Small letters indicate comparison between the days (column wise) for $1 \%$ level of significance.

Capital letters indicate comparison between different treatments (row wise) for $1 \%$ level of significance. 
Table.4 Analysis of variance using unequal factorial design with Unequal number of observations for average Body Weight (BW) before and after treatment in goats

\begin{tabular}{|c|c|c|c|c|c|c|}
\hline Source & DF & SS & MSS & F (Cal) & F - 0.05 & F - 0.01 \\
\hline SS G & 2 & 101.5081028 & 50.7540514 & 13.6337583 & 3.02 & $4.66 * *$ \\
\hline SS D & 2 & 15.77472762 & 7.88736381 & 2.11873552 & 3.02 & $4.66 * *$ \\
\hline GXD & 4 & 10.60814438 & 2.6520361 & 0.71240065 & 2.39 & $3.36 * *$ \\
\hline Error & 412 & 1533.74211 & 3.72267502 & & & \\
\hline Total & 420 & & & & & \\
\hline
\end{tabular}

Fig.1 Average Egg Per Gram (EPG) before and after treatment in goats

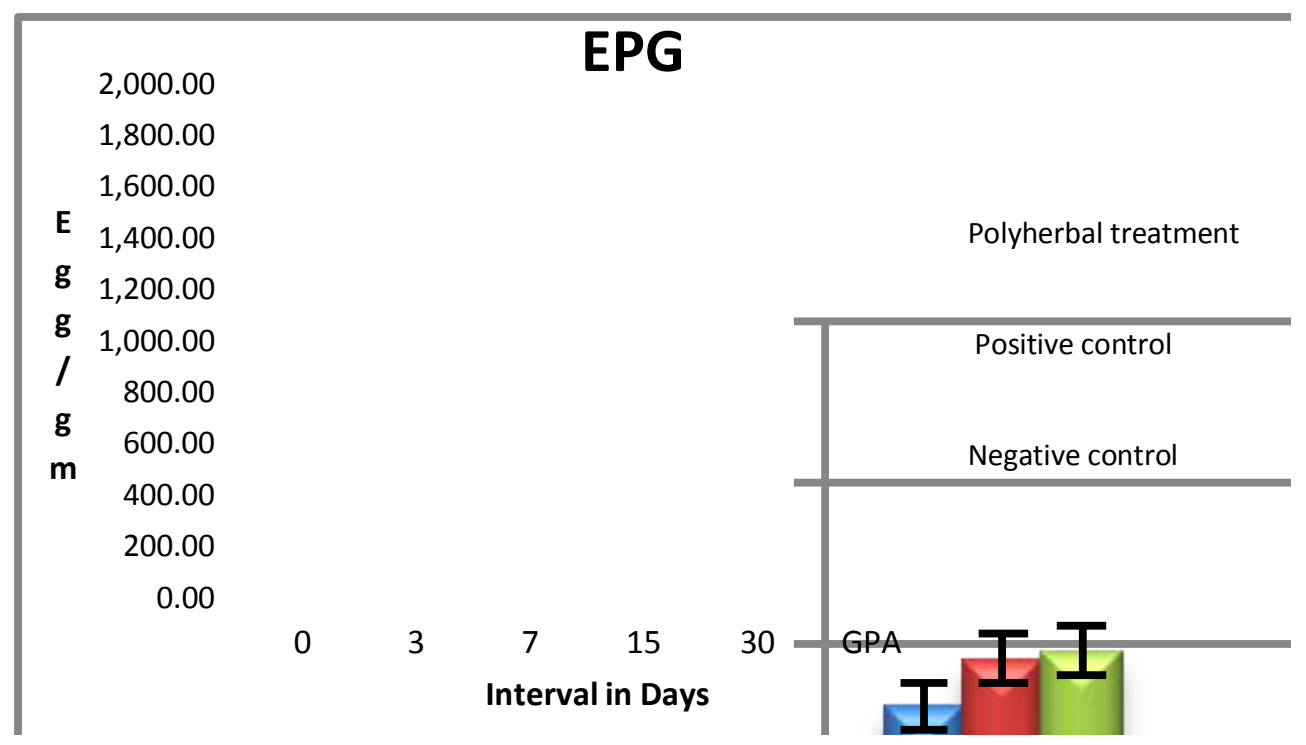

Fig.2 Average Body Weight $(\mathrm{Kg})$ before and after treatment in goats

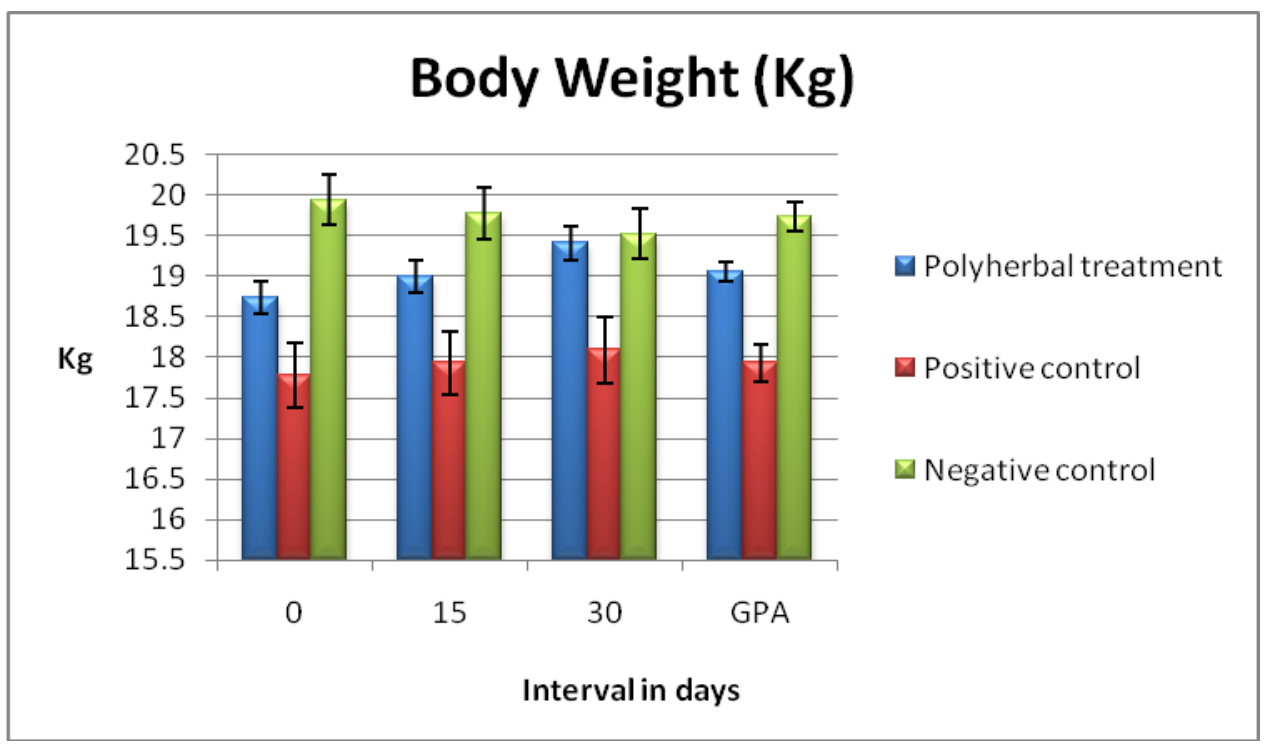


Fig.3 Rough Body coat and soiled hind quarters on the onset of trial

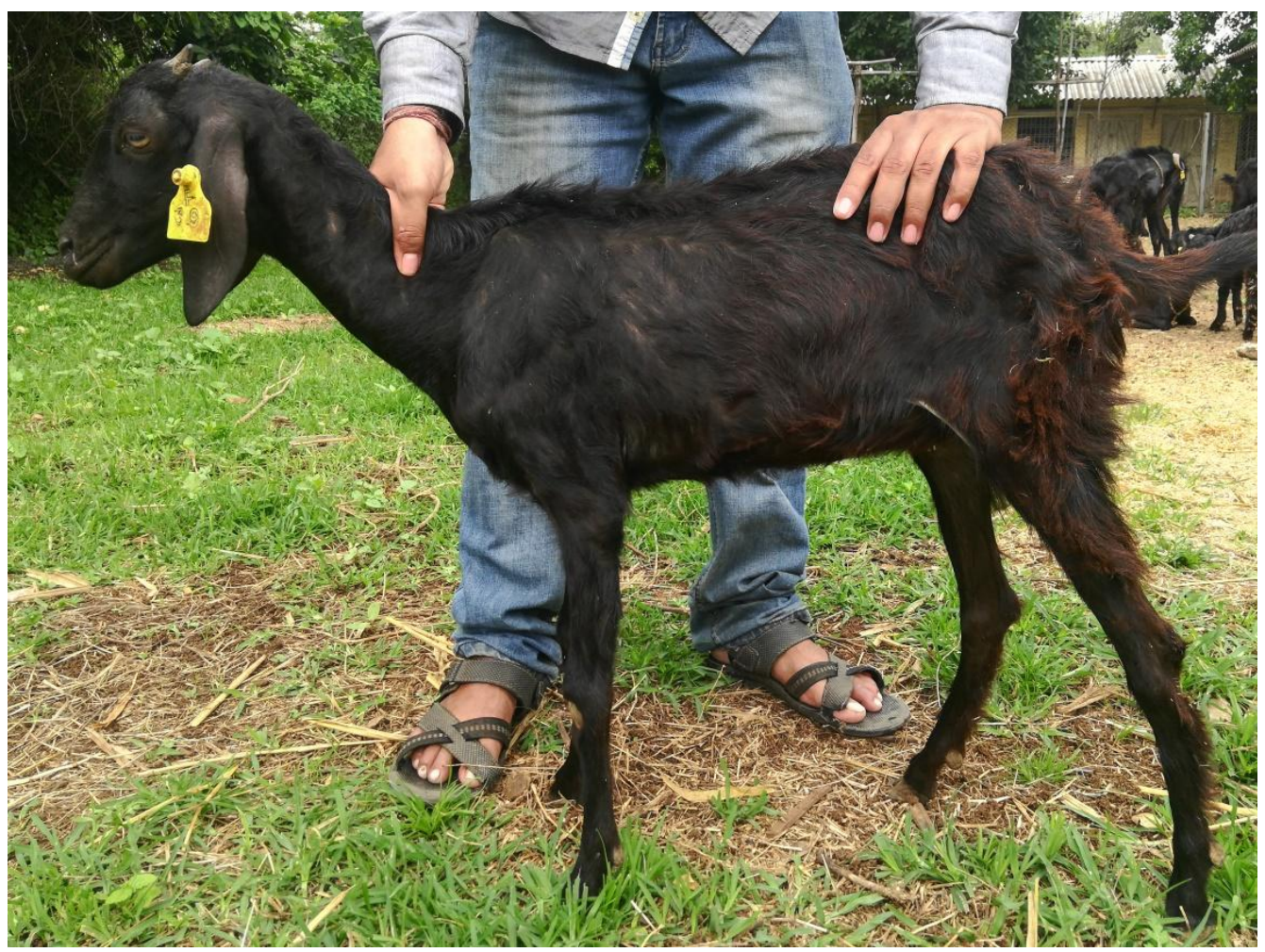

Fig.4 Improved body condition on $30^{\text {th }}$ day of trial

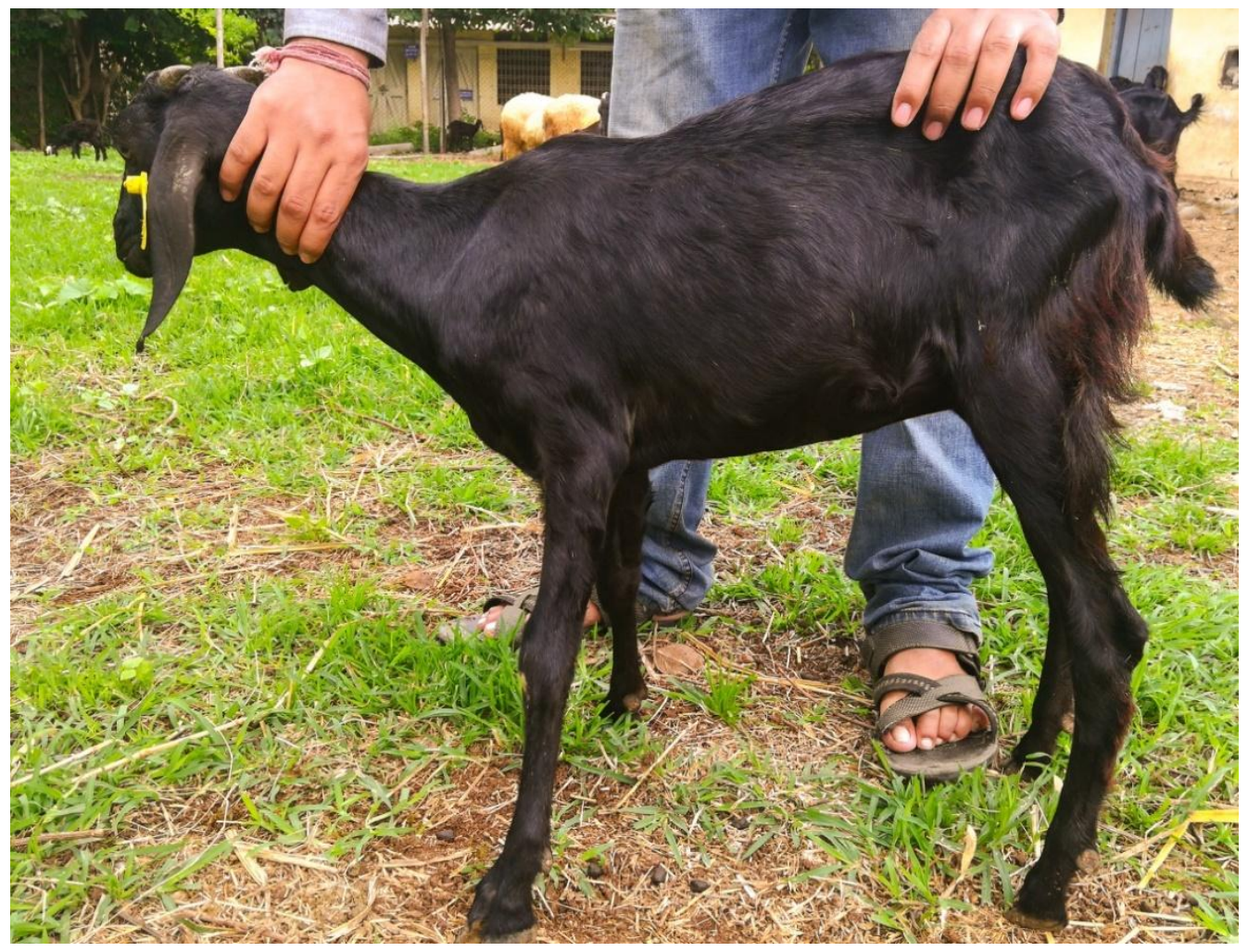


Significant $(\mathrm{P}<0.01)$ difference between average body weight in Group I was observed on 0 day, $15^{\text {th }}$ day and $30^{\text {th }}$ day, respectively. Slight increase in body weight was observed after administration of polyherbal tablet which might be due sudden elimination of $H$. contortus larvae which are voracious blood suckers, thereby the feed utilization proportion increased and hence there was gain in the body weight observed. Similar observations were recorded by Zacharias et al., (2008) in which there were weight gain observed after administration of polyherbal anthelmintic.

In Group II, significant $(\mathrm{P}<0.01)$ difference was observed in the average body weight on the onset of study and on $15^{\text {th }}$ day and $30^{\text {th }}$ day after administration of albendazole.

The average weight gain was more significant $(\mathrm{P}<0.01)$ in Group I on $30^{\text {th }}$ day after administration of polyherbal tablet as compared to Group II and Group III.

In Group III, significant $(\mathrm{P}<0.01)$ difference was observed on the onset of study and on $15^{\text {th }}$ and $30^{\text {th }}$ which could be co-related with the worm infestation. The decrease in body weight could be co-related with the gradual increase in the EPG of Group III throughout the course of study. Similar results were reported by Rahman and Collins (1990) and Abakar et al., (2000) in which they observed that when lambs infected with haemonchosis they lose body weight of $1.5 \mathrm{~kg}$ to $2 \mathrm{~kg}$ in $30^{\text {th }}$ day, respectively.

Weight gain observed in Group I on day $30^{\text {th }}$ could be co-related with the reduction in EPG values on $3^{\text {rd }}$ day, increase in $\mathrm{Hb}$ and $\mathrm{PCV}$ percentage and increase in serum total protein value on $15^{\text {th }}$ day after administration of polyherbal tablet. Due to presence of Haemonchus contortus in abomasum, there was huge loss of amino acids resulting in the damage to the mucosa which increased the level of nitrogen in the abomasum. Increased nitrogen in the abomasum might be indirectly responsible for inappetance and dehydration in goats, leading to weight loss. After administration of polyherbal tablet, the efficient elimination of $H$. contortus was observed because of the synergistic activity of the phytochemicals of four extracts of Artemisia maritima, Butea frondosa, Holarrhena antidysentrica and Vernonia anthelmintica present in the polyherbal tablet which resulted in gradual weight gain in goats.

From the study conducted, it was observed that the polyherbal anthelmintic tablet was effective in efficient elimination of Haemonchus contostus which might be the reason for significant weight gain in goats under trial. Further study could be done on various polyherbal anthelmintic formulation against Haemonchosis for a more potential anthelmintic activity.

\section{References}

Abakar, A. D., E. A. El Amin and A. Y. Osman (2000) Clinical Response to Experimental Haemonchus contortus infection in Desert Lambs. The Sudan J. Vet. Res. 16:1- 10.

Ameen, S. A., R. A. Joshua, O. S. Adedeji, A. O. Ige, B. O. Oyebanji, A. F. Ogundola and T. A. Rafiu (2006) Experimental studies on gastro-intestinal nematode infection; Clinical observations and haematological changes following Haemonchus contortus infection in West African Drarf (WAD) kids. J. Animal Veterinary Adv. 5(6): 511-514.

Biswas, S., J. Kar, M. Bayzid, S. K. Nath (2017) Combined Use of Herb Extract as Anthelmintic for Controlling GastroIntestinal Parasites and HemotoBiochemical Effect on Sheep. Global 
Journal of Medical Research: Veterinary Science and Veterinary Medicine. 17(2): 8-18.

Bora, K. S., A. Sharma (2011). The Genus Artemisia: A Comprehensive Review. Pharm. Biol. 49(1): 101-109.

Chandrawathani, P., O. Jamnah, P. J. Waller, M. Larsen, A. T. Gillespie, W. M. Zahari (2003) Biological control of nematode parasites of small ruminants in Malaysia using the nematophagous fungus Duddingtonia flagrans. Vet. Parasitol. 117: 173-183.

Chartier, C., F. Soubirac, I. Pors, A. Silvestre, J. Hubert, C. Couquet and J. Cabaret (2001) Prevalence of anthelmintic resistance in gastrointestinal nematodes of dairy goats under extensive management conditions in Southwestern France. J. Helminthol. 75: 325-330.

David I. G. (1990) A history of human Helminthology. C. A. B. International. Wallingford. 1. Pp: 75.

Ferreira, L. E., P. M. N. Castro, A. C. S. Chagas, S. C. Franca and R. O. Beleboni (2013) In vitro anthelmintic activity of aqueous leaf extract of Annona muricata L. (Annonaceae) against Haemonchus contortus from sheep. Exp. Parasitol. 134: 327-332.

Githiori, J. B. (2004) Evaluation of Anthelmintic Properties of Ethnoveterinary Plant Preparations Used as Livestock Dewormers by Pastoralists and Small Holder Farmers in Kenya. Ph.D thesis submitted to Swedish University of Agricultural Sciences, Uppsala, Sweden

Kirthikar, K. R. and Basu, B. D. (1975) Indian medicinal plants. 1(2): 784-788.

Mali, R. G. and A. A. Mehta (2008) A Review on Anthelmintic Plants. Nat. Prod. Rad. 7(5): 466-475.

McKenna, P. B., C. M. Allan, M. J. Taylor and K. G. Townsend (1995). The prevalence of anthelmintic resistance in ovine case submissions to animal health laboratories in New Zealand in 1993. New Zealand Vet. J. 43: 96-98.

Mini, K. P. K. V. Venkateswaran, S. Gomathinayagam, S. Bijargi and P. K. Mandal (2013) Anthelmintic Activity of Plants Especially of Aristolochia Species in Haemonchosis: A Review. Asian J. Anim. Vet. Adv. 10 (10): 623645.

Mohammed, A., A. Wossene, M. Giday, G. Tilahun and N. Kebede (2013) In vitro anthelminthic activities of four medicinal plants against Haemonchus contortus. Afr. J. Plant Sci. 7: 369 -373.

Panchbhai, C. G. (2018) Targeted formulation and evaluation of polyherbal anthelmintic against haemonchosis in small ruminants. Ph.D thesis submitted to MAFSU, Nagpur.

Perry, B. D., T. F. Randolph, J. McDermott, K. R. Sones, P. K. Thornton (2002). Investing in animal health research to alleviate poverty. International Livestock Research Institute. Kenya. Nairobi: 148.

Rahman W. A. and G. H. Collins (1990) Changes in live weight gain, blood constituents and worm egg output in goats artificially infected with a sheepderived strain of Haemonchus contortus. Br. Vet. J. 7:543-550.

Satpute, K., K. Bodas, V. Shende, W. Chaus, A. Dhumal., A. Galphade (2014) Anthelmintic activity of extracts of Holarrhena antidysenterica wall. World J Pharm Pharm Sci. 3 (8): 561-567.

Shah, S. M. A., U. Khan, N. Akhtar, H. M. Asif, M. Akram, K. Ahmed, G. Shaheen, T. Shamim, R. Rehman, A. Ahmad, L. Sumreen (2010) Monograph of Holarrhena antidysenterica (linn.) Wall. Int. J. Phyto med. 2: 345-348.

Soulsby, E. J. L. (1982). Helminths, arthropods and protozoa of 
domesticated animals. The English Language Book Society and Bailliere, Tindall, London. Ed. 7.

Soulsby, E. J. L., (2006) Helminths Arthropods and Protozoa of Domesticated Animals. The English Language Book Society and Bailliere Tindall, London: 765-767. Ed. 7.

Sunandhadevi, S., M. L. V. Rao, P. Dixit, A. K. Dixit, P. C. Shukla, R. P. S Baghel (2017) In vivo Anthelmintic Activity of a Herbal Formulation against Naturally Acquired Gastrointestinal Nematodes in Goats. Environment \& Ecology. 35(2A): 933-935.

Tariq, K. A., M. Z. Chishti, F. Ahmad, A. S. Shawl (2009) Anthelmintic activity of extracts of Artemisia absinthium against ovine nematodes. Veterinary Parasitology (160): 83-88.

Waller, P. J. and R. K. Prichard (1985) Drug resistance in nematodes. In: Campbell,
W. C., Rew, R. S. (Eds.), Chemotherapy of parasitic infections. Phenum. New York, USA: 339- 362.

Zacharias, F., J. E. Guimarães, R. R. Araújo, M.A.O. Almeida, M. C. C. Ayres, M. E. Bavia, F. W. Mendonça (2008) Effect of homeopathic medicines on helminth parasitism and resistance of Haemonchus contortus infected sheep. Lima Homeopathy. 97(3): 145-151.

Zafar I., M. Lateef, A. Jabbar, M. S. Akhtar, and M. Nisar Khan (2006) Anthelmintic Activity of Vernonia anthelmintica Seeds against Trichostrongylid Nematodes of Sheep. Pharm. Biol. 44(8): 563-567.

Zafar, I., M. Lateef, M. Ashraf, A. Jabbar (2004) Anthelmintic activity of Artemisia brevifolia in sheep. J. Ethnopharmacol. 93: 265-268.

\section{How to cite this article:}

Vinayak Khanolkar, C.G. Panchbhai, G.R. Bhojne, V.M. Dhoot and Athaley, A.J. 2018. Anthelmintic Efficacy of Polyherbal Formulation in Goats Naturally Infected with Haemonchus contortus. Int.J.Curr.Microbiol.App.Sci. 7(10): 2133-2142. doi: https://doi.org/10.20546/ijcmas.2018.710.245 